\title{
Pengaruh Lama Rebusan Daun Sirih terhadap Responsifitas Mastitis Sapi Perah
}

\section{Serliana Mano ${ }^{\mathrm{a}}$, Stefanus Sio ${ }^{\mathrm{b}}$, Theresia Ika Purwantiningsih ${ }^{\mathrm{c}}$}

${ }^{a}$ Fakultas Pertanian, Universitas Timor, Kefamenanu, TTU - NTT, Indonesia, email: manoserliana@gmail.com

${ }^{b}$ Fakultas Pertanian, Universitas Timor, Kefamenanu, TTU - NTT, Indonesia, email: stefsio67@ gmail.com

${ }^{c}$ Fakultas Pertanian, Universitas Timor, Kefamenanu, TTU - NTT, Indonesia, email: theresiaicha@ gmail.com

\section{Article Info}

\section{Article history:}

Received 04 Oktober 2020

Received in revised form 03 Januari 202

Accepted 20 Januari 2021

DOI:

https://doi.org/10.32938/ja.v6i1.1178

Keywords:

Celup puting

Rebusan daun sirih

Susu sapi perah

\section{Abstrak}

Mastitis merupakan peradangan ambing yang dapat disebabkan oleh masuknya bakteri melalui lubang puting. Secara ekonomi, mastitis sangat merugikan peternak karena dapat menurunkan produksi susu. Tujuan dari penelitian ini untuk memberikan alternatif larutan celup puting yang aman, murah dan mudah ditemukan oleh masyarakat dan peternak. Penelitian ini dilaksanakan pada bulan September sa mpai Oktober 2019 di Peternakan Biara Claretian Benlutu, Timor Tengah Selatan. Metode yang digunakan adalah Rancangan Acak Lengkap (RAL) yang terdiri dari 4 perlakuan 3 ulangan sehingga terdapat 12 unit percobaan. Perlakuan yang diberikan adalah sebagai berikut R0 = Air biasa, R1 = Larutan antiseptik komersial, R2 = Rebusan daun sirih 45 menit dan R3 = Rebusan daun sirih 60 menit. Variabel yang diamati adalah hasil deteksi mastitis dan uji derajat keasaman susu (uji $\mathrm{pH}$ ). Hasil penelitian menunjukkan pemberian rebusan daun sirih memberikan pengaruh yang tidak signifikan terhadap hasil deteksi mastitis dan tingkat keasaman (pH). Disimpulkan bahwa rebusan daun sirih mempunyai kemampuan yang sama dengan antisep komersil dalam mencegah terjadinya mastitis pada ternak sapi perah di Peternakan Claretian Benlutu.

\section{Pendahuluan}

Mastitis merupakan peradangan ambing yang dapat disebabkan oleh masuknya bakteri melalui lubang putting (Subronto, 2003). Secara ekonomi, mastitis sangat merugikan peternak karena dapat menurunkan produksi susu. Prevalensi mastitis pada sapi perah di Indonesia sangat tinggi $(85 \%)$ dan sebagian besar merupakan infeksi yang bersifat subklinis (Poeloengan, 2010).

Mastitis subklinis tidak menampakkan gejala klinis sehingga sering tidak disadari oleh peternak. Penyebab terjadinya mastitis diantaranya yaitu kuman patogen (infeksius) seperti bakteri dan virus; kerusakan fisik ambing (udde and teat injury); serta paparan bahan kimia iritan yang mampu merusak jaringan internal ambing, namun sebagian besar kejadian mastitis disebabkan oleh bakteri. Bakteri yang dapat menyebabkan mastitis diantaranya yaitu $S$ agalactiae, S. dysgalactiae, S. uberis, S. aureus, S. epidermidis, E. coli, E. freundii, A. aerogenes, dan K. pneumoniae (Poeloengan, 2010).

Tanaman sirih merupakan tanaman hijau yang merambat dengan daun yang berbentuk hati. Tanaman ini potensial untuk dibudidayakan karena dapa digunakan sebagai antiseptik dan obat luka (Kumari dan Rao, 2014). Sirih hijau memiliki berbagai macam khasiat karena kandungan kimia yang dimilikinya sangat banyak. Katekol, pirogalol, quinon, eugenol, flavon dan flavonoid merupakan termasuk golongan fenol dan mempunyai kemampuan sebagai bahan antimikroba (Suliantari et al., 2008). Daun sirih telah dikenal secara luas oleh masyarakat Indonesia sebagai antibakteri alami. Kandungan minyak atsiri daun sirih (Piper betle L.) dilaporkan mempunyai daya antibakteri. Hasil uji in vitro menunjukkan bahwa ekstrak daun sirih mempunyai efektivitas sebaga antibakteri terhadap S. agalactiae, S. aureus dan S. epidermidis yang diisolas dari susu sapi penderita mastitis subklinis (Poeloengan et al., 2005). Ekstrak daun sirih telah teruji dapat menghambat bakteri $S$. aureus dan E. coli. Mengekstrak daun sirih membutuhkan biaya yang mahal dan alat yang modern dan tidak semua peternak dapat melakukannya. Merebus daun sirih menjadi alternatif lain untuk mendapatkan khasiat antibakteri dari daun sirih

\section{Metode}

\subsection{Lokasi dan Waktu Penelitian}

Penelitian ini dilaksanakan mulai bulan September sampai Oktober 2019 di Peternakan Biara Claretian Benlutu, TTS.

\subsection{Materi Penelitian}

\subsubsection{Alat dan Bahan}

Alat yang digunakan untuk membuat rebusan air daun sirih adalah panci, kompor dan penyaring, paddle, tabung reaksi, gelas ukur, meter, dipper. Bahan yang digunakan dalam penelitian ini adalah susu segar, daun sirih dan aquades.

\subsection{Metode Penelitian}

Metode yang digunakan dalam penelitian ini adalah Rancangan Acak Lengkap (RAL) yang terdiri dari 4 perlakuan 3 ulangan sehingga terdapat 12 unit percobaan. Perlakuan yang diberikan adalah sebagai berikut

R0 = Air biasa

$\mathrm{R} 1$ = Larutan antiseptik komersial

R2 = Rebusan daun sirih 45 menit

$\mathrm{R} 3=$ Rebusan daun sirih 60 menit

\subsection{Prosedur Penelitian}

\subsubsection{Prosedur Perebusan Daun Sirih}

Pembuatan rebusan air daun sirih konsentrasi $50 \%$ dengan cara merebus daun sirih sebanyak 100 gram dalam 1 liter air selama 45 menit.

\subsubsection{Prosedur Celup Puting}

Celup puting dilakukan selama 1 bulan pada 4 ekor sapi perah mastitis sub klinis. Masing-masing sapi dicelup menggunakan rebusan air daun sirih, larutan antiseptik komersial dan air biasa

\subsubsection{Prosedur Uji CMT (California Mastitis Test)}

Uji CMT dilakukan pada 4 ekor sapi perah yang diduga terkena mastitis sub klinis. Uji CMT dilakukan sesudah celup puting menggunakan rebusan air daun sirih. Metode pengujian sampel susu dilakukan menurut metode Mellenberger dan Roth (2000). Langkah pertama yang dilakukan yaitu $2 \mathrm{ml}$ susu segar diambil dari setiap puting sapi sampel. Susu tersebut diletakkan di paddle dengan posisi vertikal. Larutan CMT ditambahkan kemasing-masing bagian paddle kemudian paddle CMT diputar, sehingga susu dan larutan CMT tercampur. Proses pencampuran tidak lebih dari 10 detik. Hasil yang terlihat dalam paddle CMT dibaca dengan cepat karena reaksi yang terlihat akan rusak dalam 20 detik. Penilaian reaksi ini secara visual. Lebih banyak gel yang dibentuk, semakin besar nilainya.Hasil pengujian CMT ditentukan sebagai berikut negatif (tidak terinfeksi) ditandai dengan tidak terdapat gumpalan dan sangat encer, trance (sangat ringan dan kemungkinan terjadi infeksi) ditandai dengan adanya 0 gumpalan dan reaksi ini akan menghilang jika paddle diputar lagi, positif 1 (infeksi ringan) ditandai dengan larutan yang mengental akan tetapi tidak condong menjadi gel, jika paddle diputar lebih dari 20 detik kekentalan menghilang, positif 2 (terinfeksi) ditandai dengan terjadi gumpalan dan membentuk gel yang ringan, campuran akan menggumpal di tengah paddle dan akan melapisi bagian bawah apabila dibuang dan positif 3 (terinfeksi kuat) ditandai dengan terbentuknya gel yang sangat kental dan sulit untuk digerakkan.

\subsection{Variabel Penelitian}

Variabel yang diamati adalah deteksi mastitis melalui uji CMT dan $\mathrm{pH}$ susu.

\subsection{Analisis Data}

Data yang diperoleh dalam penelitian ini dianalisis dengan sidik ragam sesuai Rancangan Acak Lengkap (RAL) dan dilanjutkan dengan menggunakan Uji Jarak Berganda Duncan (Steel dan Torrie, 1991). Model matematisnya adalah $: Y i j=\mu+\tau i+€ i j$.

Keterangan :

Yij = Nilai pengamatan dengan ulangan ke-

$\mu=$ Rata-rata umum (nilai tengah pengamatan)

$\tau \mathrm{i}=$ Pengaruh perlakuan ke-i $(\mathrm{i}=1.2,3,4,5)$

$€ \mathrm{ij}=$ Galat percobaan dari perlakuan ke-i pada pengamatan ke-j $(\mathrm{j}=1,2,3,4)$

\section{Hasil dan Pembahasan}

\subsection{Deteksi Mastitis}

Susu merupakan sumber protein hewani yang sangat lengkap bagi kebutuhan tubuh masyarakat. Kualitas susu yang baik juga berasal dari ternak yang sehat. Kualitas susu yang rendah sangat tidak baik untuk dikonsumsi. Salah satu faktor yang mempengaruhi penurunan kualitas susu sapi perah adalah peradangan ambing (Mastitis). Untuk mencegah hal tersebut harus dilakukan uji pada ternak. Salah satu cara untuk mengetahuinya adalah dengan melakukan deteksi mastitis (CMT). California Mastitis Test adalah salah satu cara untuk mengetahui penyakit radang ambing pada ternak sapi perah, seperti yang dijelaskan oleh Pradiee et al. (2012) bahwa California Mastitis Tes (CMT) merupakan salah satu metode diagnosa mastitis subklinis yang sampai saat ini dianggap sederhana dan cepat yaitu metode dengan menggunakan ala yang disebut paddle dan menggunakan reagen $C M T$ untuk mengetahui tingkat keparahan mastitis subklinis yang dialami. Hasil penelitian uji $C M T$ yang diberi perlakuan celup putting menggunakan ekstrak rebusan daun sirih dapat dilihat pada Tabel 1

Uji CMT akan memberikan informasi sapi yang terserang mastitis melalui penggumpalan susu (Adriani, 2010). Hasil uji CMT pada ternak sapi di Peternakan Claretian Benlutu yang telah dicelup menggunakan ekstrak rebusan daun sirih tidak memberikan perbedaan yang nyata. Hal ini dapat dikatakan bahwa ekstrak rebusan daun sirih memiliki kemampuan yang sama dengan larutan antisep komersil. Kandungan fenol yang terkandung dalam sirih hija 
diyakini memiliki kandungan lebih banyak dibanding fenol pada umumnya. Fenol dapat menghambat aktivitas bakteri penyebab mastitis pada ternak sapi perah. Mekanisme fenol sebagai agen antibakteri adalah sebagai toksin dalam protoplasma, merusak dan menembus dinding serta mengendapkan protein sel bakteri. Senyawa fenolik bermolekul besar mampu menginaktifkan enzim essensial di dalam sel bakteri meskipun dalam konsentrasi yang sangat rendah.

Tabel 1. Hasil uji California Mastitis Test (CMT) pada ambing ternak yang telah dicelup menggunakan rebusan daun sirih dan antisep komersil.

\begin{tabular}{|c|c|c|c|}
\hline Nomor Sapi & Jenis larutan & Puting Susu & Rata-rata CMT \\
\hline \multirow{4}{*}{1} & \multirow{4}{*}{ Air (kontrol +) } & Kiri Depan & - \\
\hline & & Kiri Belakang & - \\
\hline & & Kanan Depan & - \\
\hline & & Kanan Belakang & + \\
\hline \multirow{5}{*}{2} & Rata-rata & & 0,25 \\
\hline & \multirow{4}{*}{ Antiseptik Komersial } & Kiri Depan & + \\
\hline & & Kiri Belakang & - \\
\hline & & Kanan Depan & + \\
\hline & & Kanan Belakang & + \\
\hline \multirow{5}{*}{3} & Rata-rata & & 0,75 \\
\hline & \multirow{4}{*}{$\begin{array}{l}\text { Rebusan daun sirih } \\
\text { konsentrasi } 50 \% \text { (45 } \\
\text { menit) }\end{array}$} & Kiri Depan & - \\
\hline & & Kiri Belakang & + \\
\hline & & Kanan Depan & - \\
\hline & & Kanan Belakang & - \\
\hline & Rata-rata & & 0,25 \\
\hline \multirow{4}{*}{4} & \multirow{4}{*}{$\begin{array}{l}\text { Rebusan daun sirih } \\
\text { konsentrasi } 50 \% \text { (60 } \\
\text { menit) }\end{array}$} & Kiri Depan & - \\
\hline & & Kiri Belakang & - \\
\hline & & Kanan Depan & - \\
\hline & & Kanan Belakang & - \\
\hline & Rata-rata & & 0 \\
\hline
\end{tabular}

Mahardika et al. (2016) menjelaskan bahwa perlakuan teat dipping menurunkan jumlah sel somatik pada air susu sapi perah. Sel somatik di dalam air susu terutama terdiri dari leukosit dan beberapa dari sel epitel. Peningkatan jumlah sel somatik di dalam air susu menunjukkan adanya gangguan di dalam kelenjar susu terutama peradangan pada kelenjar susu akibat infeksi mikroorganisme atau mastitis. Menurut Sudarwanto (1999), indikator penting untuk mendiagnosis adanya mastitis yaitu meningkatnya jumlah sel somatik di dalam air susu. Untuk menghitung jumlah sel somatik dapat dilakukan dengan metode langsung misalnya Breed atau secara tidak langsung dengan menggunakan alat California Mastitis Test (CMT).

Teat dipping selain dapat menggunakan antiseptik kimia juga bisa menggunakan ekstrak dari tanaman obat. Beberapa tanaman telah diketahui mempunyai aktivitas antibakteri sehingga bisa digunakan untuk teat dipping. Hasil penelitian Kurniawan et al. (2013) menggunakan dekok daun kersen (Muntingia calabura. L) dengan konsentrasi 20\% memiliki kemampuan menurunkan tingkat kejadian mastitis sebesar $80 \%$. Hasil penelitian Zalizar (2012), sediaan minyak bawang putih (garlic oil) dapat menghambat pertumbuhan bakteri $S$. agalactiae. Bawang putih memiliki aktivitas anti peradangan dengan menurunkan kadar TNF-a (Ziamajidi et al., 2017).

Povidone iodine mempunyai spektrum luas dan merupakan iodine kompleks yang berfungsi sebagai antiseptik yang dapat menghambat pertumbuhan mikroba yang ada di dalam atau di atas jaringan hidup (Brooks $e t$ al., 2008). Aplikasi celup puting menggunakan povidone iodine dapat menghambat pertumbuhan bakteri dengan cara melapisi lubang puting, sehingga mikroba yang masuk ke dalam lubang puting terlapisi oleh zat iodium yang dapat merusak dinding sel bakteri bagian luar dan membran sel, kemudian menembus sitoplasma sampai ke inti sel dengan merusak metabolisme sel mikroba sehingga perkembangbiakan bakteri akan terhambat sampai akhirnya bakteri mati (Mahardhika et al., 2012). Penggunaan povidone iodine adalah solusi sederhana dan ekonomis untuk mengurangi infeksi.

\section{2 pH Susu}

Susu sapi berasal dari sapi perah yang merupakan sumber protein, lemak, karbohidrat, mineral dan vitamin. Dalam mengkonsumsi susu sapi perlu diketahui keadaan kualitas susu tersebut yang telah diperah dari ternak. Susu sapi yang baik harus berasal dari ternak yang sehat, terutama pada ambing ternak sapi yang memproduksi susu. Dalam penelitian ini diberi perlakuan pencelupan puting dengan menggunakan rebusan daun sirih dan diukur tingkat derajat keasaman pada susu atau $\mathrm{pH}$ untuk mengetahui kualitasnya. Hasil penelitian uji derajat keasaman dengan melakukan celup puting menggunakan rebusan daun sirih dapat dilihat pada Tabel 2

Uji ini dilakukan untuk menentukan keasaman susu dengan menghitung log konsentrasi ion hidrogen (asam) dalam susu. Pada prinsipnya susu segar mempunyai $\mathrm{pH}$ netral. Tingkat keasaman susu menurun karena fermentasi laktosa menjadi asam laktat oleh mikroba (Suardana dan Swacita, 2009). Dalam skala $\mathrm{pH} 1$ sampai 14 , asam mempunyai skala yang lebih rendah antara 0 sampai 7 sedangkan basa mempunyai skala yang lebih tinggi antara 7 sampai 14, maka dari itu $\mathrm{pH} 7$ dianggap netral. Normalnya $\mathrm{pH}$ pada susu dapat disebabkan karena adanya kasein, buffer, fosfat, dan sitrat. Dari skala tersebut diketahui bahwa $\mathrm{pH}$ susu di Peternakan Claretian Benlutu bersifat asam karena pH susu antara 0-7.
Tabel 2. Hasil pH susu pada ambing ternak yang telah dicelup menggunakan rebusan daun sirih dan antisep komersil.

\begin{tabular}{|c|c|c|c|}
\hline Nomor Sapi & Jenis larutan & Puting Susu & Rata-rata Uji pH \\
\hline \multirow{4}{*}{1} & \multirow{4}{*}{ Air (kontrol -) } & Kiri Depan & 6,19 \\
\hline & & Kiri Belakang & 6,07 \\
\hline & & Kanan Depan & 5,99 \\
\hline & & Kanan Belakang & 6,53 \\
\hline \multirow{5}{*}{2} & Rata-rata & & 6,19 \\
\hline & \multirow{4}{*}{ Antiseptik Komersial } & Kiri Depan & 5,97 \\
\hline & & Kiri Belakang & 5,94 \\
\hline & & Kanan Depan & 5,92 \\
\hline & & Kanan Belakang & 6,01 \\
\hline \multirow{5}{*}{3} & Rata-rata & & 5,95 \\
\hline & \multirow{4}{*}{$\begin{array}{l}\text { Rebusan daun sirih } \\
\text { konsentrasi } 50 \% \text { (45 } \\
\text { menit) }\end{array}$} & Kiri Depan & 6,05 \\
\hline & & Kiri Belakang & 5,97 \\
\hline & & Kanan Depan & 6,28 \\
\hline & & Kanan Belakang & 6,05 \\
\hline \multirow{6}{*}{4} & Rata-rata & & 6,09 \\
\hline & \multirow{4}{*}{$\begin{array}{c}\text { Rebusan daun sirih } \\
\text { konsentrasi } 50 \% \text { (60 } \\
\text { menit) }\end{array}$} & Kiri Depan & 6,03 \\
\hline & & Kiri Belakang & 5,93 \\
\hline & & Kanan Depan & 5,99 \\
\hline & & Kanan Belakang & 5,94 \\
\hline & Rata-rata & & 5,98 \\
\hline
\end{tabular}

Data pada Tabel 2, menunjukkan bahwa hasil uji $\mathrm{pH}$ susu yang diberi perlakuan rebusan daun sirih berbeda tidak nyata. Hal ini dikarenakan lama waktu pencelupan yang diberi pada puting dan juga $\mathrm{pH}$ susu di Peternakan Claretian Benlutu berkisar antara 5,9- 6,1 dan belum sesuai dengan standar SNI karena nilai pH susu segar berdasarkan SNI 3141.1:2011 yaitu 6,3 sampai dengan 6,8 (BSN 2011). Di dalam daun sirih hijau, terdapat zat antibakteri yaitu flavonoid dan tanin. Daun sirih memiliki kemampuan yang sama dengan larutan antiseptik komersial dalam menghambat bakteri penyebab mastitis.

Lama pencelupan yang dilakukan dengan rebusan daun sirih pada ternak sapi perah di Peternakan Claretian Benlutu dengan waktu 10 detik. Lama waktu dipping ini sudah sependapat dengan penelitian Putri et al. (2015), bahwa perlakuan dipping menggunakan larutan kaporit $0,2 \%$ dengan lama waktu 10 detik sudah mampu meminimalkan cemaran bakteri dan cenderung meningkatkan $\mathrm{pH}$ susu ke arah netral. Tetapi masih belum menetralkan $\mathrm{pH}$ susu di peternakan Claretian Benlutu. Dengan demikian faktor utama penyebabnya dikarenakan sistem pemeliharaan dan pemerahan pada puting susu masih bersifat manual dan juga kebersihan kandang yang belum dijaga dengan baik sehingga adanya aktivitas mikroorganisme yang tercemar pada susu. Kenaikan dan penurunan $\mathrm{pH}$ ditimbulkan dari hasil konversi laktosa menjadi asam laktat oleh mikroorganisme aktivitas enzimatik (Manik, 2006). Bila pH menjadi 6 dapat disebabkan karena kolostrum atau aktivitas bakteri pembusuk. Nilai $\mathrm{pH}$ susu yang meningkat akan menyebabkan viskositas susu juga meningkat sebagai akibat pecahnya butiran kasein (Wendt et al., 1998).

\subsection{Kerusakan Susu}

Kerusakan susu dapat diketahui dengan cepat menggunakan uji alkohol. Uji alkohol merupakan suatu uji untuk menentukan sifat-sifat pemecahan protein susu. Uji alkohol menjadi positif bila susu mulai asam atau sudah asam dan susu bercampur dengan kolustrum. Deteksi kerusakan susu di Peternakan Claretian Benlutu setelah celup puting dapat dilihat pada Tabel 3.

Tabel 3. Hasil uji alkohol susu pada ambing ternak yang telah dicelup menggunakan rebusan daun sirih dan antisep komersial.

\begin{tabular}{|c|c|c|c|}
\hline Nomor Sapi & JenisLarutan & Puting Susu & Kerusakan Susu \\
\hline \multirow{4}{*}{1} & \multirow{4}{*}{ Air (kontrol +) } & Kiri Depan & + \\
\hline & & Kiri Belakang & - \\
\hline & & Kanan Depan & - \\
\hline & & Kanan Belakang & - \\
\hline & Rata-rata & & 0,25 \\
\hline \multirow{4}{*}{2} & \multirow{4}{*}{ Antiseptik Komersial } & Kiri Depan & + \\
\hline & & Kiri Belakang & + \\
\hline & & Kanan Depan & + \\
\hline & & Kanan Belakang & - \\
\hline & Rata-rata & & 0,75 \\
\hline \multirow{5}{*}{3} & \multirow{4}{*}{$\begin{array}{l}\text { Rebusan daun sirih } \\
\text { konsentrasi } 50 \% \text { (45 } \\
\text { menit) }\end{array}$} & Kiri Depan & - \\
\hline & & Kiri Belakang & - \\
\hline & & Kanan Depan & - \\
\hline & & Kanan Belakang & - \\
\hline & Rata-rata & & 0 \\
\hline \multirow{5}{*}{4} & \multirow{4}{*}{$\begin{array}{l}\text { Rebusan daun sirih } \\
\text { konsentrasi } 50 \% \text { (60 } \\
\text { menit) }\end{array}$} & Kiri Depan & - \\
\hline & & Kiri Belakang & - \\
\hline & & Kanan Depan & - \\
\hline & & Kanan Belakang & - \\
\hline & Rata-rata & & 0 \\
\hline
\end{tabular}

Berdasarkan analisis statistik, kerusakan susu pada ternak sapi di peternakan Claretian Benlutu yang telah dicelup menggunakan air, antiseptik komersial, rebusan daun sirih yang direbus 45 dan 60 menit tidak memberikan 
perbedaan yang nyata hal ini dapat dikatakan bahwa rebusan daun sirih memiliki kemampuan yang sama dengan larutan antisep komersial. Uji alkohol positif ditandai dengan adanya butiran susu yang melekat pada dinding tabung reaksi sedangkan tidak terdapat butiran butiran menandakan uji alkohol negatif (Suardana dan Swacita, 2004). Peningkatan produksi susu nasional perlu diimbangi dengan pendayagunaannya secara optimal sehingga secara langsung dapat dikonsumsi oleh masyarakat kota dan pedesaan. Penilaian mutu dan produksi susu sering digunakan sebagai tolak ukurnya adalah berdasarkan uji kualitas susu terhadap komposisi susu dan keadaan fisik susu, uji kualitas susu dapat ditinjau dari uji alkohol yang merupakan pemeriksaan terhadap keadaan susu yang berguna untuk memeriksa dengan cepat keasaman susu, menentukan adanya kuman-kuman pada air susu (Hadiwiyoto, 1994) dimana susu segar mengandung bakteri pembentuk asam seperti Streptococcus dan Lactobacillus. Uji alkohol dilakukan untuk mengetahui adanya susu yang rusak, apabila terdapat butir-butir susu pada dinding tabung menunjukkan susu tersebut positif telah rusak. Susu segar yang berkualtas baik tidak akan pecah atau menggumpal bila dipanaskan atau dididihkan. Sebaiknya, susu yang bermutu jelek akan mengalami penggumpalan bila dipanaskan. Hal ini terjadi karena adanya asam yang dihasilkan oleh mikroba pengurai laktosa. Asam tersebut mengakibatkan protein susu mudah mengalami denaturasi dan penggumpalan bila dilakukan pemanasan (Ace dan Wahyuningsih, 2010).

\section{Simpulan}

Pemberian rebusan daun sirih memberikan pengaruh yang signifikan terhadap hasil deteksi mastitis dan tingkat keasaman $(\mathrm{pH})$. Rebusan daun sirih mempunyai kemampuan yang sama dengan antiseptik komersil dalam mencegah terjadinya mastitis pada ternak sapi perah di Peternakan Claretian Benlutu.

\section{Pustaka}

Ace, L. S dan Wahyuningsih. 2010 Hubungan Variasi Pakan terhadap mutu susu segar di desa pasirbuncir kecamatan caringin kabupaten bogor. Jurnal Penyuluhan Pertanian, 5 (1) 67-77.

Adriani. 2010. Penggunaan somatik cell count (SCC), jumlah bakteri dan california mastitis test (CMT) untuk deteksi mastitis pada kambing. Jurnal Ilmu-Ilmu Peternakan, 13(5): 229-234.

Badan Standardisasi Nasional [BSN]. 2011. SNI 3141.1:2011 tentang Susu Segar Bagian-1: Sapi. Jakarta (ID): BSN.

Brooks, G. F., Butel, J. S., Morse, S. A. 2008. Mikrobiologi Kedokteran. Ed ke-23. Nugroho, E., Maulany, penerjemah.. Terjemahan dari: Medical Microbiology. EGC. Jakarta. Indonesia: $544 \mathrm{hlm}$.

Hadiwiyoto, S. 1994. Teori dan Prosedur Pengujian mutu susu dan hasil olahannya. Edisi ke-2 Liberty, Yogyakarta.

Kumari, O. S. dan N. B. Rao. 2014. Phyto chemical Analysis of piper betel leaf extract. World Journal of pharmacy and pharmaceutical sciences, Telangana.

Kurniawan, I., Sarwiyono dan P. Surjowardojo. Pengaruh teat dipping menggunakan dekok daun kersen (Muntingia calabura L.) terhadap tingkat kejadian mastitis. Jurnal Ilmu-Ilmu Peternakan, 23 (3) : 27-31.

Mellenberger, R and C.J. Roth. 2000. California Mastitis Test (CMT). Fact Sheet.

Mahardhika, O., Sudjatmogo, Suprayogi, T. H. 2012. Total bacteria and pH of goat milk with various udder dipping methods. Anim. Agric. J, 1(1):819828

Mahardika, H.A., P. Trisunuwati dan P. Surjowardojo. 2016. Pengaruh suhu air pencucian ambing dan teat dipping terhadap jumlah produksi, kualitas dan jumlah sel somatik susu pada peternakan sapi peranakan Friesian Holstein. Buletin Peternakan, 40 (1):11-20.

Manik, E. 2006. Olahan Susu. Jakarta : Pusat Unit Pangan dan Gizi. IPB. Bogor.

Poeloengan M. 2010. Aktivitas air perasan dan ekstrak etanol daun encok terhadap bakteri yang diisolasi dari sapi mastitis subklinis.Prosiding Seminar Nasional Teknologi Peternakan dan Veteriner; 2009 Agu 1314; Bogor, Indonesia. Hlm 300-305.

Poeloengan, M., Susan, M.N dan Andriani. 2005. Efektivitas Ekstrak Daun Sirih (Piper betle Linn)Terhadap Mastitis Subklinis. Seminar Nasional Teknologi Peternakan dan Veteriner 2005. Halaman 1015 - 1019

Pradiee, J., C.R. Moraes., M. Goncalves., M.S. Vilanova., G.F. Correa., O.G. Lauz., M.T.M. Osorio., dan V. Schmidt. 2012. Somatic Cell Count and Californi Mastitis Test as a Diagnostic Tool for Subclinical Mastitis in Ewes. Acta Scientiae Veterinariae, 40 (2) 1038 : 1-7.

Putri, P., Sudjatmogo, T.H, Suprayogi. 2015. Pengaruh lama waktu dipping dengan menggunkan larutan kaporit terhadap tampilan total bakteri dan derajat keasaman susu sapi perah. Animal Agric. Jour, 4 (1) :132-136.

Sudarwanto, M. 1999. Usaha Peningkatan Produksi Susu Melalui Program Pengendalian Mastitis Subklinis. Orasi Ilmiah, 22 Mei 1999.Fakultas Kedokteran Hewan. Institut Pertanian Bogor

Steel, R and Torrie, J 1991. Prinsip Dan Prosedur Statistika Suatu Pendekatan Biometrik. PT. Gramedia Pustaka Utama. Jakarta.

Subronto. 2003. Ilmu Penyakit Ternak I. Gajah Mada Univ. Press. Yogyakarta. Indonesia: $701 \mathrm{hlm}$.
Suliantari, B.S.L., Jenie, M. T., Suhartono dan Apriyantono, A., 2008. Aktivitas Antibakteri Ekstrak Sirih Hijau (Piper betle L.) Terhadap Bakteri Patogen Pangan. Tesis. Program Pasca Sarjana. Institut Pertanian Bogor.

Suardana, I. W., dan Swacita, I. B. N, 2009. Higiene Makanan. Kajian Teori dan Prinsip Dasar. Udayana University Press.

Suardana, I. W. dan I. B. N. Swacita. 2004. Food Hygiene. Petunjuk Laboratorium. Fakultas Kedokteran Hewan Universitas Udayana, Denpasar

Wendt, K., K.H. Lottheimer, K. Fehlings, and M. Spohr. 1998. Handbuch Mastitis Kamlage Veriage. GmbH and Co., 49082 Osnabruck.

Zalizar, L. 2012. Kualitas Fisik Garlic Oil Dan Potensinya Sebagai Antimikroba Streptococcus Agalactiae Penyebab Mastitis Pada Sapi Perah. Jurnal Gamma, 7 (2) : 53-60.

Ziamajidi, N., Nasiri, A., Abbasalipourkabir, R dan Moheb, S.S. 2017. Effects of garlic extract on TNF- $\alpha$ expression and oxidative stress status in the kidneys of rats with $\mathrm{STZ}+$ nicotinamide induced diabetes Pharmaceutical Biology, 55:1, 526-531. 